IBAD Sosyal Bilimler Dergisi

IBAD Journal of Social Sciences

dergipark.org.tr/ibad

IBAD, 2021; (9): 447-461

DOI: $10.21733 /$ ibad. 844931

Özgün Araştırma / Original Article

\title{
Divan Şiirinde “Nân-pâre” Kavramı ve Bu Kavramın Divan Şairleri Tarafından Kullanımı
}

The Concept of "Nân-pâre" in Divan Poetry and Its Use by Divan Poets

\author{
Vesile Albayrak Sak ${ }^{1 *}$ \\ * Sorumlu yazar \\ Corresponding author
}

${ }^{1}$ Dr. Öğr.Üyesi, Necmettin Erbakan Üniversitesi, Türkiye

Assist. Prof.Dr., Necmettin Erbakan University, Turkey

Albayrak_vesile@hotmail.com:

ORCID ID 0000-0001-5343-1099

Makale geliş tarihi / First received : 22.12.2020

Makale kabul tarihi / Accepted $\quad$ : 10.02.2021

Bilgilendirme / Acknowledgement:

Yazar aşağı daki bilgilendirmeleri yapmaktadır:

1- Makalemizde etik kurulu izni ve/veya yasal/özel izin alınmasını gerektiren bir durum yoktur.

2- Bu makalede araştırma ve yayın etiğine uyulmuştur.

This article was checked by Turnitin. Similarity Index 21\%

\section{Atıf bilgisi / Citation:}

Albayrak Sak, V. (2021). Divan Şiirinde “Nân-pâre” Kavramı ve Bu Kavramın Divan Şairleri Tarafından Kullanımı. IBAD Sosyal Bilimler Dergisi, (9), 447-461. 


\section{ÖZ}

Osmanlı'da padişahtan müneccime, vezirden çizmeciye çok çeşitli meslek mensubu insan genelde sanatla özelde şiirle uğraşmış; hem sayıca çok hem de zevkte çeşitlilik arz eden eserler ortaya çıkmıştır. İçinde bulunulan sosyal ve ekonomik koşullara bağlı olarak yardıma ihtiyaç duyan şairler gelenek çerçevesinde padişah ve şehzade başta olmak üzere geçimi ile ilgisi olan alt veya üst kademedeki kişilere hatta varlıklı kişilere başvurmuştur. Padişah ve devletin ileri gelenlerinin lütfuna mazhar olarak geçimini sağlayıp durumunu düzeltmeye uğraşan bu şairler kaside, gazel, kit 'a vb. eserler kaleme alarak in'âm, ihsân, atâ, lütuf, bahşiş, câize gibi gelenek itibarıla var olan bu kavramlarla yardım talep etmişlerdir. Bu kavramlardan biri de "nân-pâre"dir. Kelime anlamı olarak ekmek parçası, ekmek dilimi anlamındaki ifade mecazen geçimini sağlayacak iş, memuriyet, gelir yani ekmek parası anlamında kullanılmış; zor durumda olan şairler içinde bulundukları geçim sıkıntısını anlatmada bu kavramı tercih etmişlerdir. Çalışmamız nân ve pâre kelimelerinden oluşan bu kavramın divan şairleri tarafından hâllerinin arzında hangi anlamlarda ve nasıl kullanıldığını ortaya koymayı amaçlamaktadır.

\section{Anahtar kelimeler}

Divan şiiri, nân-pâre, divan.

\section{ABSTRACT}

In the Ottoman Empire, people who were the members of various professions, from sultan to astrologer, vizier to bookmaker, generally involved in art, especially poetry; works that vary in number and in terms of taste have emerged. Depending on the social and economic conditions, the poets in need of help, referred to the senior and junior administrative people who were related to their livelihood, and even to wealthy people, especially to the sultan and the shahzade. These poets, who earned their livelihoods and tried to improve their position by winning the favour of the sultan and the notables of the state, wrote eulogy, ode, verse, etc., and asked for help with concepts such as donation, gift, munificence, grace, tip, charity. One of these concepts is "nân-pâre". The expression, which means a piece of bread, a slice of bread, is used figuratively in the meaning of the job that will provide a living, civil service, income; our poets, who were in a difficult situation, preferred this concept to describe their financial hardship. Our study aims to reveal in what meanings and how this concept, which consists of the words nân and pâre, was used by our divan poets.

\section{Keywords}

Divan poetry, nân-pâre, divan. 


\section{GíRiş}

Osmanlı Devleti'nde sanata ve sanatçıya verilen değerin bir anlamda delili olan in'âmât defterleri, inâyât ve ihsan fermanları devletin şairleri koruyup kolladıklarının ve onları teşvik ettiklerinin somut göstergeleridir. Zira Gazneli ve Selçuklular döneminde oluşturulan edebî geleneği devralan (Armutlu, 2002, s. 878) 23 Osmanlı padişahının divan sahibi olması (Atalar, 1981, s. 427), ilk şiir söyleyen, şairlere aşırı ilgi gösteren (İpekten, 1996, s. 21) ve duygularını nazım hâlinde söylediği ifade edilen (Şardağ, 1982, s. 39) II. Murad'dan itibaren son müstakil divan sahibi III. Selim'e kadar sultanların şiire ve şaire artarak alaka göstermeleri bu teveccühün bir delilidir. Sultanların şairlere gösterdikleri bu teveccüh seferlerde dahi sürmüş, beş büyük sefere çıkan Kanuni Sultan Süleyman tarafından sefer sırasında dahi in'âmât yapılmıştır (Erünsal, 1984, s. 2).

Ekâbir, vüzerâ, ümerâ, kuzât gibi ifadelerle anılan sadrazam, vezirler, beylerbeyi, şeyhülislamlar, kazaskerler, kadılar, uç beyleri gibi meslek sahipleri kimi zaman padişah ve şehzadeye ulaşmada bir basamak teşkil etmişler kimi zaman da saray ve çevresine ulaşmaya muktedir olamamış şairlerin ulaştığı çevreler olmuşlardır (Güler ve Yaşar, 2007, s.7).

Edebî ve ilmî eserlerin yazarına geçimi için yeterince gelir kaynağı sağladığı dönem gelinceye kadar sanatkâr ve âlim, hükümdarın ve seçkin sınıfın desteğine ihtiyaç duymuş (İnalcık, 2003, s. 1) devlet-sanat ilişkisi birlikteliğinin hem saltanat hem de sanatçı açısından karşılıklı memnuniyete dayanan boyutu olmuştur. Her iki tarafın da sanat noktasında üretici olması yani hâmînin de şiir yazması, edebiyatla uğraşması onları sadece kendilerine şiir sunulan makam olmaktan çıkarmış (Durmuş, 2009, s. 16), şiirin dolayısıyla edebiyatın özel destekleyicisi konumuna getirmiş; saraylarını, konaklarını yüksek sanat anlayışının ortaya çıkmasını sağlayan sanat mekânları yapmıştır. Şiire ve şaire sunulan bu maddî ve manevî desteğin taşrayı da kapsaması şiirin diğer sanat dalları arasında daha güçlü olmasına sebep olmuştur.

\section{Kültürümüzde Nân/Ekmek}

Tahıl unundan yapılmış hamurun fırında, sacda veya tandırda pişirilmesiyle yapılan yiyecek olarak tanımlanan nân/ekmek, insanoğlunun en temel besinlerinden biri olarak tarihin her döneminde önemini korumuş; arpa, buğday, çavdar çeşidi ne olursa olsun yenilen her şey anlamını da ihtiva edecek şekilde geniş bir anlam evrenine sahip olmuştur. Tarihin en eski dönemlerinde yevmiyelerin ekmek üzerinden belirlenmesi, ekmeğin meşru yollardan kazanılmasının vurgulanması, toplumsal değerlerin yaşatılması ve aktarılmasında ekmeğe önemli rol yüklemiştir. Dinî ve kültürel hayatın her anına yansıyan bu kutsal değer edebî eserlere de yansımış, Türk dilinin ve edebiyatının en eski yazılı kaynağı olan Göktürk Kitabeleri'nden başlayarak bütün edebî eserlerimizde karşılığını bulmuştur. Yazıtlar'da “Ökinlig bişdi/ekinler oldu." (Orkun, 1994, s. 279), Divan-1 Lugati't-Türk'te “Ol manga etmek uwuşd1/O bana ekmek ufalamakta yardım etti." (Atalay, 1985, s. 185), Kutadgu Bilig'de "Tuz ekmeğini king tut kişige yitür, kişi aybı körse sen açma yitür/Tuz ekmeğini çok tut kişiye yedir, kişinin ayıbını görsen sen açma, ört." (Arat,1979, s. 150) şeklinde ifadelerle yer alır. Tasavvufun Anadolu'daki önemli temsilcilerinden Mevlâna'nın Mesnevî'sinde de ekmek pek çok beyitte geçmektedir. Bu beyitlerden birinde, küflü ekmek yiyen ve kendisine açgözlü oluşunun nedenini soran bir adamın verdiği: "Sabrın sonucunda açlık, iki misli arttı mı arpa ekmeği bile bana helva gelir." (İzbudak, 1991, s. 232) cevabında ise arpa ekmeği, nefsi sembolize eder. 
Ekmek insan hayatıyla o kadar iç içedir ki bütün dinler tarafından kutsal sayılan bu besin Türk kültüründe üzerine yemin edilen, asla atılmayan, yerlerde bırakılmayan her daim yüceltilen "nân-1 azîz" olmuştur. Değerli ve kutsal maddelerin başında gelen ekmek, bir başka kutsal maddeyi, tuzu beraberine almış, gücünü kültür ve inanç sisteminden sağlayan bu maddeler anlam evrenini genişleterek edebiyatımızda vefa hakkını ifade için kullanılmıştır (Albayrak Sak, 2020, s. 96). Ekmeğe ve tuza verilen kıymet "nankör" kelimesiyle de kültürümüzde çokça kullanılmaktadır. Farsça nân/ekmek, kûr/kör birleşmesiyle oluşan kelime, gördüğü iyiliği unutan, tuz ekmek hakkını bilmeyen (Devellioğlu, 1992, s. 964), iyilikbilmez anlamındadır.

\section{Nân-pâre Kavramı Hakkında}

Nân-pâre geçim için verilen vazife; geçim vasıtasıyla çıraklık hakkında kullanılan tabir; memuriyet, bir iş isteği hakkında resmî makamlara verilen arzuhâllerle büyüklere yazılan isti’tafnâme (şefkat ve inayet dileği); ekmek parçası, ekmek dilimi anlamlarında kullanıldığı gibi zarurete düşenler için söylenen "nân-pâreye muhtaç" tabirinde ise hem ekmek parası hem de zarurete düşmüş anlamında (Pakalın, 1993, s. 654; Şemseddin Sami, 1317, s. 1452) kullanılmıştır. Türk kültüründe en temel besin ögelerinden olan, bazlama, büskeç, sünçü, pide (Ögel, 1978, s. 37) gibi adlarla da anılıp alın terinin, bereketin sembolü olan ekmeğe ait kavramlardan biri olarak da karşımıza çıkmaktadır.

İfadenin orduya asker sağlamak için geliştirilmiş Osmanlı dirlik sistemiyle ilgisi mevcuttur. Mülkiyeti devlete ait arazinin rakabesinin veya menfaatinin hazinede istihkakı bulunan kimseye ulu'l-emr tarafından verilmesi yerinde kullanılan ikta ve a'da ile cenk etmesi mukabelesinde tayin olunan yani fetih sirasında arazi-yi emriyye itibar edilen yerlerden sipahilerle zaimlere kılıç hakkı olarak verilen Beytü'l-mal hissesi olan tımar bu sistemin temelini teşkil eder. Ayrıca zeamet ve tımar gibi mukayyet olmayıp zevât-ı muhtelifeye sadaretten azil ve tekâüt edilen vezirlere, harpte hüsn ü hizmeti sebk edenlere, tenkil-i eşkıyaya, sefere memur olanlara, bir mahallin muhafazasını yapanlara, bir kalenin tamirine memur edilenlere verilen şey veya küçük payeleri olan ilmiye ricaline tahsis olunan maaş demek olan arpalık (Pakalın, 1993, s. 1-495-84-85) ile birlikte bu düzen daha çok ordunun finansında kullanılmıştır.

Nân-pâre kavramına, Nizâmü'l-Mülk'ün Siyasetnâme'sinde de rastlanmaktadır. Büyük Selçuklu Devleti'ne otuz yıl vezirlik yapmış "vezir-i mâderzâd" olarak nitelendirilen devlet adamı Nizâmü'l-Mülk, bilgi, görgü ve tecrübesi; idarî, malî, askerî alanlarda aldığı tedbir ve düzenlemeleri ile Türk-İslam devletleri tarafından örnek alınmıştır. Siyasetnâme' de beş yerde kullanılan kelime "Vezirlerin ve Mutemetlerin Hâllerine Dair" başlıklı bir hikâyede de geçmekte, tımar sahibi bir askere eziyet edip nân-pâresini elinden alan Râst Ruşen isimli vezire Behrâm-1 Gûr'un verdiği ceza anlatılmaktadır (Nizâmü'l-Mülk, 2013, s. 29). Eserde kavram "arpalık, ikta sisteminde tahsis olunan yerler ve askerlere, memurlara yapacakları hizmetleri karşılığında ödenen ücret, aylık" olarak ifade edilmektedir.

\section{Nân-pâre Kavramının Şiirlerde Kullanımı}

Çeşitli ihtiyaçlara sahip şairler hâllerinin tercümanı olarak şiiri yüzyıllar boyunca kullanmışlardır ki zaten böyle bir geleneğin içinde yer alan padişah ve üst düzey devlet adamları için bu durum ne yadırganmış ne de kötü karşılanmıştır. Kalemine güvenen şairler için şiir XVI. yüzyıl şairlerinden Cinânî'nin III. Murad'a sunduğu "Kaside-i Câme"de olduğu gibi (Batislam, 2006, s. 12) bazen elbise veya Sâbit'in Halil Paşa'dan talep ettiği gibi saat; Fazıl 
Ahmed Paşa'ya kasideler sunan Sünbülzâde Vehbî'de olduğu gibi bazen bir mansıp bazen de Haşmet gibi bağışlanması için bir af vesilesi olmuştur.

Sâmî'nin divanında III. Ahmed ve Şehid Ali Paşa'nın cömertliklerinden bahsetmesi ve Paşa'nın maiyetinde bir müddet Edirne'de yaşaması korunduğunun göstergesidir. Damad İbrahim Paşa'ya sunduğu bir kasidesinde ise babadan kalma eviyle eşyalarının yandığı ve maddî sıkıntı çektiği anlaşılmaktadır. Şair beyitte ayın yüzeyindeki leke ve noktaları, kanaat sofrasının ekmek kırıntılarına benzetmiş, güneşin gücün kaynağı olduğunu söylemiştir.

Çün kurs-ı meh sirişte-i bâzû-yı mihr olur

Nân-pâre-i simât-1 kanâ'at didükleri

Sâmî (Kutlar Oğuz, 2017, s. 381)

Abdülahad Dede'ye intisap ederek Tokat Mevlevîhânesi'ne devam eden Ebû Bekir Kânî, Defterdar Osman Efendi'ye yazdığı kasidesinde ondan umduğu ihsanı çörek, kendisinin teşekkürünü de nân- pârecik kelimesiyle dile getirir. Şair, memuriyetten elde edilen gelirinin oldukça yetersiz olduğunu, inayete muhtaç olduğunu şu nükteli anlatım ile ifade etmektedir:

Sen çörek ben de saña nân-pârecik yapdurayum

İnşa'allah gör niçe sa'yı sevî meşkûr olur

Kânî (Yazar, 2017, s. 92)

Bir asra yakın bir ömür süren Sünbülzâde Vehbî Efendi, XVIII. yüzyılda sekiz Osmanlı padişahının devrini idrak etmiştir. Bu padişahlar; III. Ahmed (1703-1730), I. Mahmud (17301754), III. Osman (1754-1757), III. Mustafa (1757-1774), I. Abdülhamid (1774-1789), III. Selim (1789-1807), IV. Mustafa'dır (1807-1808) (Uzunçarşılı, 1988, s. 331-350). III. Selim adına tertip ettiği ve kasidelerin önemli bir yer tuttuğu divanında Sünbülzâde Vehbî, III. Selim'e sunduğu kasidelerle mansıp isteğini dile getirir. Mekke, olmazsa Kudüs kadılığına razı olduğunu söyleyen şaire III. Selim, birçok hediyeler ile şahsî elbiselerinden meydana gelen bir bohça hediye etmiştir. İtibarı gittikçe artan Vehbî'nin Sultan III. Selim'in saltanat yılları hayatının en parlak devresi olmuştur. Yine III. Selim döneminde "sultanü'ş-şuarâ" unvanını da alan ve mimarî eserler için düşürdüğü tarihler İstanbul'un çeşitli yerlerini süsleyen Vehbî'nin kadılık mesleğinden önce müderrislik yaptığı ve sunduğu kasideler münasebetiyle kurduğu dostlukların neticesinde Rumeli ve Anadolu'nun birçok yerinde kadılıklarda bulunduğu ancak fiyasko ile sonuçlanan İran elçiliği sonrasında ise kendisi gibi hâmîlerinin de gözden düşmesi sebebiyle gittikçe geçim sıkıntısı çektiği ifade edilir (Yenikale, 2017, s. 8). Kaside sunduğu devlet büyüklerinden yardım göremeyen şair 7 yıllık fakr u zaruret içindeki bekleyişten sonra sadrazam Halil Hamid Paşa'nın yardımıyla kadılığa dönebilmiştir. Mansıp taleplerini kasidelerine borçlu olan Vehbî, III. Selim'e sunduğu 71 beyitlik kasidesinde; sanmayın ki şu ay ve güneş halka ekmek verir, cihanı dolaşan onun lütfunun ekmek parçasıdır, ifadeleriyle memduhu III. Selim'den inayet beklemiştir.

Nân-pâre-yi 'inâyetidir dehri seyr eden

Șanmañ şu ḳurș-1 mihr ü mehi halḳa nân verir ～Vehbî (Yenikale, 2017, s. 297)

Toplum hayatındaki bozukluk, oğlunun ölümü, evinin soyulması, bulunduğu görevler esnasında sık sık azledilmesi sebebiyle derbeder bir hayat yaşamak zorunda kalan Malatyalı Şehrî, Kethüda Mustafa Ağa'ya yazdığı methiyede "Ey kerem sahibi, yüce huzura bir 
arzuhâlim var, mübarek başın için başımdan geçenleri dinleyip ihsan kıl." demekte ardından da "Yüce sofradan bana nân-pâreyi çok gördü. Künyemin üzerine zulüm kalemi ile hükümsüz diye bir çizgi çekti" şeklinde sitemlerini belirtmektedir ki dirlik sahibi olduğu, bir nedenden dolayı bunun elinden alındığı ve bu yüzden oldukça sıkıntılı günler geçirdiği (Demirel, 2017, s. 5) ifade edilmektedir.

Baña çoḳ gördi bir nân-pâreyi ol ḩ̌ân-1 ‘ựmâdan

Esâmum üzre çekdi kilk-i zulm ile hạaț-1 buṭlân Şehrî (Demirel, 2017, s. 51)

Asıl adı Mehmed olup Abbas Efendizâde sanıyla tanınan Haşmet, Râgıb Paşa'nın meclislerinde bulunmuş; Paşa'nın dostluğunu kazanarak ona kasideler sunmuş, hâriç ve daha sonra dâhil rütbesini elde etmiş, müderrislikte sahna kadar yükselmiştir. İzmir ve Bursa'ya sürgün edilen şair, Bursa'da sıkıntılı bir hayat geçirmemesine rağmen, bağışlanması için Râgıb Paşa'dan aracılık yapmasını ister. Bursa' da altı yıla yakın kalır, babasının mirasını harcayarak renkli bir hayat sürer (Aksoyak ve Arslan, 2018, s. 5). Gazelindeki bir beyitte, Haşmet bildiğim şu ki o ihsana muhtaç olan, devletin yüksek tabakasına mensup kişilerin sayesinde çoğunlukla gam yer, diyerek sitem eder.

\section{Sâyesinde gam yer ekser hasret ol nân-pâreye}

Bildigim Haşmet kibâr-1 devlete mensûblar

Haşmet (Aksoyak ve Arslan, 2018, s. 147)

Nakşibendî şeyhlerinin büyüklerinden Behcet Ali Efendi'nin müridi olan, müderrislik yapan ve 1835 'te vefat eden Bursalı İffet'in varlıklı bir aileden geldiği tahmin edilmektedir. İffet'in, önceleri zengin ve müreffeh bir hayat sürerken, hayatının bir döneminde belki de son dönemlerinde, bazı maddî ve manevî sıkıntılar yaşadığı ifade edilir (Arslan, 2018, s. 3). Bu durumu diğer kaynaklar belirtmemiş olmasına rağmen Gülzâr-ı İrfân şu cümlelerle ifade eder:

"Nice şuhûr u sâl ginâ-i hâl ile müreffehü'l-bâl iken, hayli zamân çille-i teng-destî ile perîşânü'l-hâl oldıgından mâ-'adâ, düşmen-i ehl-i dil olan sipihr-i gaddâr beyyinesinden her ân gördigi sûret-i cevr ü sitem ve her bâr yâr-ı gârı eczâ-i yedinden bulunan derd ü elem ve bi-hikmet-i Hudâ sâkî-i devrân elinden içdigi bâde-i endûh u gam idi." (Atlansoy, 1998, s. 377).

Dişleri yokken ekmek dilimi geldiğini söyleyen şair geç kalan lütuf için feleğe daha doğrusu ihsan sahiplerine sitem etmektedir.

Biz kâni`iz ki gayri çerâg eylesün felek

Nân-pâremiz ki nîstî-i dendân iken gelür

İffet (Arslan, 2018, s. 37)

İffet Efendi, anladık bildik redifli gazelinde de çeşit çeşit insan gördüğ̈̈nü,bu insanlarda insanlığın yararına kullanılan bilgiden, hünerden, irfandan eser olmadığını belirtip cihanın alçaklarını bir ekmek parçasına anladık bildik, diyerek zamaneden şikâyet etmektedir.

Ma'ârifden eser yok devlete magrûr u kâni’ hep

Birer nân-pâreye dûnân-1 dehri añladık bildik İffet (Arslan, 2018, s. 54) 
XVII. yüzyıl şiirini etkisi altına alan Sebk-i Hindî üslûbunun başlıca temsilcisi olan Nâ'ilî, Halvetiye tarikatının bir kolu olan, İbrahim Gülşenî’nin kurduğu Gülşeniyye tarikatı mensubudur. Babasının da çalıştı̆̆ı Mâden kalemine memur olarak girip baş halifeliğe kadar yükselen şair kendi ifadelerine göre "fakr u zaruret" içinde yaşamış, kasidelerinde yaşadığ hayattan yakınmış, durumunu düzeltecek bir koruyucu aramıştır. Hayatını bir düzene sokabilmek için padişahtan başlayarak sadrazam, şeyhülislam, vezir, defterdar gibi devletin ileri gelenlerine kasideler sunan Nâ'ilî, Sadrazam Sâlih Paşa ile Defterdar Mehmed Paşa'ya yakınlaşıp onlardan yardım görse de bu yardımlar geçici olmuş, bir süre sonra şair yine korumasız kalmıştır. Ömrünün son yıllarını sürgünde geçiren Nâ'ilî, IV. Mehmed'e sunduğu "şitâ'iyye" kasidesinde bu acıları dile getirmiş, bağışlanması için uğraşmıştır. Bağışlanan Nâ'ilî’nin İstanbul'a dönüp Fâzıl Ahmed Paşa'nın ilgisini ve yardımlarını gördüğü kasidelerinden anlaşılmaktadır (İpekten, 2019, s. 3). Şair, sefillerle dolu yer ehline ekmek parçası yok, cihan sofrasının rızık yetiştireninin hikmetini bilen yok, diyerek tasavvufî bir bakış açısıyla cihanın rızkını yetiştiren Allah'a dikkat çekmiş̧ir.

İmtilâ-gâh-1 esâfil ehline nân-pâre yok

Hª̂n-ı dehrün hikmet-i rûzî-resânın kim bilür

Nâ'ilî (İpekten, 2019, s. 347)

İzzet Ali Paşa, divan şiirinin XVIII. yüzyılın ilk yarısında yetişen devlet adamı şairlerindendir. Mektupçuluk, defterdarlık, vezirlik, kaymakamlık gibi görevlerde bulunmuş, ilim heyetine dâhil edilmiş, Revan seraskeri iken orada vefat etmiştir. Kaynaklar onun liyakat sahibi, yetenekli, dürüst bir devlet adamı, cömert, nüktedan bir insan olduğu konusunda söz birliği etmiş gibidirler. Özellikle daha sonraki adıyla "Lâle Devri" diye anılan dönemi idrak etmiş, III. Ahmed döneminin ihtişamlı günlerini ve hazin sonunu görmüştür. Ancak bu hazin sona dair şiirlerinde bir işaret bulunmamaktadır (Kutlar Oğuz, 2019, s. 25). O, yaşadığı eğlenceli dönemi ve özelliklerini canlı bir şekilde anlatmayı, döneminin olumlu özelliklerini şiire yansıtmayı tercih etmiş görünse de gazelindeki bir beyitte:

Bu cihanın nân-pâresini elde edeyim dersen ay gibi artış ve eksilişi aynı bil, diyerek paşa dahi olsa inişli çıkışlı bir hayatın olabileceğini ifade etmiştir. 40 yaşına girmeden üç tuğla vezirlik payesi alan yani sayısı vazifenin derecesine ve ehemmiyetine göre değişen hükümdarlık, vezirlik, beylerbeyilik, sancak beyliği gibi görev ve memuriyet işareti sayılan tuğların (Çoruhlu, 2012, s. 331) sahibi İzzet Ali Paşa azledilip sürülünce gurbette yaşamış, hayatının bir karesinde de olsa zorluk çekmiştir.

\section{Tev'emân bil kâhiş ü efzâyişin çün ḳurș-1 mâh}

Olayım derseñ bu dehriñ nâ'il-i nân-pâresi

İzzet Ali Paşa (Kutlar Oğuz, 2019, s. 238)

Divanından son derece sefil ve münzevî bir hayat yaşadı̆̆ı anlaşılan ve Saîd mahlasıyla divan tertip eden Saîd Giray'ın hayatı hakkında kaynaklarda bilgi yoktur. 1645'te Osmanlı hakimiyetini tanıyan Kırım Hanlığı geliştirilen bir sistemle Osmanlı tarafından tayin edilen hanın Giray unvanını almasıyla veliahdı (Nûreddinler) emniyet gereği İstanbul'da ikâmet ediyor, tedrisat görüyorlardı. Devlete itaat ve bağlılık için han kardeşlerinden birinin rehine olarak İstanbul'da ikameti mecburi idi. Saîd Giray'ın rehine olarak İstanbul'a gelmiş olabileceği, III. Osman'a yazdığı (ö. 1757) methiyeden de III. Ahmed, I. Mahmud ve III. 
Osman'ın saltanatı yıllarında yaşamış olabileceği ifade edilir. Oğlu Halîm Giray'ın kardeşi Mengli Giray yerine III. Osman tarafından Kırım Hanlığı'na getirilmesi sebebiyle memnuniyetini ifade etmiştir. Ne var ki 1774 'te Küçük Kaynarca antlaşmasıyla Kırım'ın bağımsızlığını elde edip Osmanlı'dan ayrılmasıyla olumsuz siyaset gütmüştür (Karaköse, 2017, s. 5-6).

Saîd Giray, İstanbul'da bulunduğu süre içerisinde geçim sıkıntısı çekmiştir. Sık sık, ekâbirin kerem sahibi olmadıklarını, hatta selamını almadan önce ceplerini kontrol ettiklerini dile getirir. İlim ve irfana rağbet edilmediğini, insanların paraya hürmet ettiklerini ifade eder. Borç içinde yaşadığını, borçlarını veremediğini ve borç bile bulamadığını anlatır. Divanda "karz" redifli iki gazel bulunmaktadır. Şair, Rûm elinde çok zor günler geçirmiş ve kendini adeta mahpus gibi hissetmiştir. "Rûm-1 şûm, kâfir Rûm" terkiplerini kullanmaktan kaçınmayan şair çok fazla maddî sıkıntı çektiğini, ilme sanata değer verilmediğini, ekâbirin cimriliğini dile getirir. Bir taraftan sıla özlemiyle yanarken, diğer taraftan kendini garip, değersiz ve yabancı hisseder. Terkib-i bendi tamamen İstanbul'daki yaşantısını ve duygularını dile getirmesinin yanında, "Kuru ekmek parçasına kanaat et, üzülme, halkın malının gasbedildiği, buna engel olmanın güçleştiği dönemde gam yemektense kuru ekmek yemeye razı ol." diyerek bozulan düzenden de dem vurur.

Kâni'-i nân-pâre-i huşk ol Sa'îdâ gam yime

Gasb-1 mâl-i halka sâhib-i nevâl olmak da güç

Saîd Giray (Karaköse, 2017, s. 62)

Şair içinde bulunduğu durumdan ve yaşadığı sıkıntılardan, cihanda kuru ekmek parasını kazanayım diye kendisini pervane gibi alçakların kapısında döndüren talihini sorumlu tutar.

Cihânda dest-res olsun diyü nân-pâre-i huşkuñ

Beni pervâne-âsâ gird-i bâb-1 dûn iden tâli‘

Saîd Giray (Karaköse, 2017, s. 91)

Saîd Giray, mansıp için baştan geçenlerin muradına erdiği görülmez mi, diyerek serzenişte bulunur. Şairin nân-pâre kavramını mansıp/mevki, makam anlamında kullandığını görüyoruz.

Bulur ‘ayş-1 şenî şîr-i nefesi eyleyen maktûl

Görülmez mi olur nân-pâreye nâ'il geçen serden

Saîd Giray (Karaköse, 2017, s. 108)

Mehmed Çelebi olarak anılan XVI. Yüzyıl şairi Hayretî, Vardar Yenicesi'ndendir. Hayatı Rumeli ve İstanbul'da geçen şairin mesleğinin sipahilik olduğu, kardeşi Yusuf-1 Sîneçâk gibi onun da Gülşenî tarikatına intisap ettiği anlatılır (Çavuşoğlu ve Tanyeri, 1981, s. XII-XIV).

Hayretî aşağıdaki beytin alındığı yok redifli gazelinde şanssızlığından, vefasızlıktan bahsetmekte, aşk yarasından başka kendisini bir aydır yiyecek ekmek parçası olmayan bir öksüz olarak anlatmaktadır. 
Koynumda dâğ-1 sîneden özge bir öksüzin

Bir aya deñlüce yinicek nân-pâre yoḳ

Hayretî (Çavuşoğlu ve Tanyeri, 1981, s. 251)

Enderunlu Ferîd İbrahim XIX. yüzyılın ilk yarısında İstanbul'da yaşamış son dönem Osmanlı şairlerinden olup 1842 yılında ölmüştür. Kaynaklarda Üsküdar Yeni Cami Mütevellisi ve Surre Emini Ferid İbrahim Bey olarak adı geçen, 1258/1842 tarihinde Surre-i Hümayun Emaneti hizmetiyle güney Hicaz'a gönderilen şairin II. Mahmud zamanında yaşadığı, onun saltanatı döneminde kendisine tevliyet ihsanında bulunulduğu düşürdüğü tarihlerden anlaşılmaktadır. Sultan Mahmud'a yazdıgı methiyede şair birinci beyitte, dört senedir beklediğini, bu gecikmiş ihsana nân-pârenin yetmeyeceğini dile getirmekte; ikinci beyitte ise yine çok zor durumda olduğunu belirterek geçim sıkıntısı derdine çare için adeta yalvarmakta, imdat istemektedir.

Dört sene böylece mațlûb-1 tedâhülde ḳalup

Bu güżeşteye yetişmez șanurım nân-pâre

Ferîd (Çobanoğlu, 2006, s. 10)

Meded Allâh için ol şâh-1 cihân için

Ġayrı nân-pâre ile derdime eyle çâre

Ferîd (Çobanoğlu, 2006, s. 10)

Osmanlı devlet teşkîlâtında yazı işlerinin başında, defterdarlık, nişancılık gibi memûriyetlerde, eminlik ve müdürlüklerde bulunanlar için kullanılan hâcegân/hâcegânlık II. Mahmud'a kadar belli memûriyetlerde bulunanlara verilen unvanken II. Mahmud'dan sonra padişahça bağışlanan bir rütbe olmuştur. Ferîd, nân-pâre olarak hâcegânlık vazifesini talep etmektedir.

Bir du'âcı bende-i dergâh-1 'adliñdir seniñ

Ġayrı bir nân-pâre iḥsânıñla olsun ḩ̌acegân

1227/1812 Ferîd (Çobanoğlu, 2006, s. 101)

Seyyid Ahmed Paşa'nın sakal bırakmasını tebrik etme amaciyla düşürdüğü tarihte de yine ihsan beklediğini ifade eder.

Ferîdâ yaz bu târîh-i tamâmıñ 'arż-1 tebrîke

Ebû nân-pâre alup lihye irsâl eyledi esrâr

1227/1812 Ferîd (Çobanoğlu, 2006, s. 55)

Celali İsyanları bitmiş olsa da Urfa ve çevresinde yaptığı tahribatın hâlâ devam ettiği yıllarda toprağında mutlu olmayan ve İstanbul'a gitmeğe karar veren (İsen, 2012, s. 47) Nâbî, içindeki "azîmet et" sesine kulak vererek devletin başkentine geldiğini “Der Senâ-yı Musâhib-i Şehriyârî̀ Mustafa Paşa" başlıklı manzumede anlatır. İlk zamanlarda İstanbul'da aradığını bulamayan şairin Musâhib Mustafa Paşa'nın yanına divan kâtibi olarak girmesiyle rahat hayat şartları içinde şiir ve sanat alanında inkişaf ettiği görülür. Paşa vasıtasıyla da IV. Mehmed'in iltifatına nail olur (Kaplan, 2012, s. 13). Bu durumu şair, şayet o kerem sahibi himmet edip rahat bir geçim sağlamasaydı...ifadeleriyle verir. 
Şâyed ol pür-kerem idüp himmet

Sana bir nân-pâre-i râhat

Nâbî (Bilkan, 1997, s. I/405)

Şair yine Allah'ın takdir ettiği rızkı engellemeye çalışan insanlara kızarak Rezzâk'un/Allah'ın verdiği rızka kimsenin mani olamayacağını belirtir.

Men 'i nân-pâremüze kûşiş iden câhil-i dûn

Degül a men ine kâdir kerem-i Rezzâkun

Nâbî (Bilkan, 1997, s. II/795)

1650 civarında doğmuş olabileceği düşünülen Sâbit, imamlık, kadılık görevlerinde bulunmuş; kırk akçe maaşla müderrisliğe yükselip ma'zul olduktan sonra, bir süre görevden uzak kalmış, bu süreçte çok fazla sıkıntı çekmiştir. Şair, Sadrazam Merzifonlu Kara Mustafa Paşa (ö. 1683)'ya çok fazla borcu olduğunu, kötü talihi ve acımasız kişilerin verdiği sıkıntı yüzünden acı çektiğini belirterek yardımını istemiştir. XVII. yüzyılın siyasî ve sosyal hayatına parelel olarak her gün el değiştiren mevki ve rütbeler şairin başını döndürmüş, mansıp isteğiyle devrin büyüklerine kasideler sunmuştur. Bosna kadılığı sırasında Halil Paşa'dan saat göndermesini isteyen şair, Paşa'nın kendisine gönderdiği saate ve hatta pirince duyduğu sevinci şu beyitle ifade eder:

Ȟ̌ân-1 cûd-1 Halîl Pâşâdan

Toldı matbah erizle hınca hinç

Sâbit (Karacan, 1981, s. 42)

Fakirliğinden bahsile dostlarına bile selam vermekten çekindiğini söyleyen şair, Paşmakçıâde Seyyid Ali Efendi'yi övdüğü kasidesinde, daima yardıma muhtaç kimse geçimini sağlayacak azıcık yardım ne zaman elime geçecek diye gözler durur, diyerek beklentisini ifade eder.

Me'lûf-1 luṭf u 'âtịfetüñdür baḳup țurur

Bir nân-pârecikle ne gün behre-yâb olur

Sâbit (Karacan, 1981, s. 271)

Gazelindeki bir başka beyitte de, kuru ekmek parçası/çok az gelire kanaat etmek mümkün değil. Nefsin arzusuyla haram kazanç sağlamak da zor, diyen şairin yaşadığı sıkıntılarda ikilemde kaldığını da görüyoruz.

Şübhesiz nân-pâre-i ḩuşke ḳanâ'at mümteni'

Ârzû-yı nefs ile meyl-i ḥarâm itmek de güc

Sâbit (Karacan, 1981, s. 440)

Asıl adı Mehmed Sa'id (1850-1918) olan ve mahlası kendisine Ankara valisi Sırrı Paşa tarafından verilen Yozgatlı Fennî, "Sa'id" mahlasını da kullanmış, çeşitli sebeplerle gurbete çıkmıştır. Gittiği her yerde değişik kabiliyetleri sayesinde üdebâ meclislerine giren, meşhur kimselere mühürler kazıyan şair, şiirler, kasideler, nazireler yazmış ve önemli bulduğu olaylar için de tarih düşüren manzumeler, beyitler söylemiştir. Devrin padişahına, bir kısım vezir, vali ve paşalara yazdığı kasidelerin bazısını sahiplerine takdim etme fırsatını da bulamayan Fennî İstanbul'a gidip bizzat saray erkânına ulaşmayı ömrü boyunca hayal etmiş, bir defasında bu amaçla yola çımış ancak maddî imkânsızlıklar yüzünden Ankara'ya kadar varıp daha ileriye gidemediği için ümidi kırık olarak geri dönmüştür (Ergin, 1996, s. I-VIII). Şair feleğe çatmış onun olgun kimselerin dişini sökmeden ya da zihinlerindeki zevk duygusunu gasbetmeden karşılıksız ekmek parçası vermediğini belirtmiş̧ir. 
Ya dendânın söker ya gasb eder zevki dimâgından

Felek nân-pâreyi ehl-i kemâle bî-bedel vermez

Fennî (Ergin, 1996, s. 136)

1570-1631 yılları arasında yaşamış Hâletî, Hoca Sadeddin Efendi'den ders almış; Kahire, Bursa, Edirne İstanbul kadılıklarında bulunmuş, Anadolu ve Rumeli kazaskerliğine atanmıştır. Ne var ki zaman zaman iftiralarla karşı karşıya kalmıştır. Sultan II. Osman'a sunduğu arzuhâlde şair pek çok sıkıntılar çektiğinden, devrin kendisini bunalttı̆̆ından ve üzdügünden, sahip olduğu hünerin akranları arasında hasede yol açtığından bahseder (Kaya, 2017, s. 22). Kaside, gazel, mesnevi vadilerinde üstat olan şair en çok da rubaileriyle şöhret kazanmıştır. Kaleme aldığ 615 rubaisi onun dünya ve hayat karşısında daha uhrevî bir yaklaşımı benimsediğini ortaya koyar. Hâletî 411 numaralı rubaisinde: Feleğin gam sofrasında hüzün ekmeği daima hazırdır. Himmet kilidinin yaptı̆̆ı işi bilmez. Zamane demircisi her daim çilingirdir yani himmet kilidinin neden yapıldığını/himmetin nasıl elde edileceğgini bilmez de ona türlü türlü anahtarlar uydurmaya çalışır,der.

Hูª̂n-1 ġam-1 çarh muntaẓırdur dâ'im

Nân-pâre-i ġușșa mâ-hażardur dâ'im

Bilmez 'amel-i kilîd-i himmet nic'olur

Ḥaddâd-ı zamâne ḳufl-gerdür dâ'im

Hâletî (Yerdelen, 1991, s. 228)

XVII. yüzyıl şairlerinden Fasîh Ahmed Dede rahat bir hayat sürmüş, hazine kâtipliği görevini terk edip 1670'li yılların başında Mevlevî şeyhi Gavsî Dede'ye intisap etmiştir (Çı1pan, 1991, s. 9). Bu fânilik evinde/dünyada ay gibi güzel sevgili başta gerek, ey felek bize ekmek parçasını çok görme, diyerek bunların gönlünde yeri olmadığını ifade etmiştir.

Bu ḩ̌ânçe-i fenâda meh-i nev serde gerek

Bir nân-pâreyi bize çok görme iy felek

Fasîh Ahmed Dede (Çıpan, 1991, s.174)

İlk Divan'ını 26 yaşında tertip eden Gelibolulu Mustafa Âlî, bu tarihten vefatına kadar "Âlî”" mahlasıyla yaklaşık 34 yıl şiir yazmış, hayatının sonuna kadar yazdığı manzumeleri, değişik zamanlarda tertip edilen dört divanda toplamıştır. Çeşitli devlet görevlerinde bulunan şair, 1578 'den sonra sık sık tayin ve azillerle karşılaşmış, III. Murad'a geçim sıkıntısı çektiğini ifade etmiştir. Şair hilale benzettiği sevgiliyi felek meclisinde şaraba bulaşmıs ekmek dilimi olarak anlatmaktadır.

Bezm-i felekde șanma şafaḳ içre mâh-1 nev

Âlûdedür şarâb ile bir nân-pâredür

Âlî (Aksoyak, 2006, s. 662)

Bugünkü Bulgaristan sınırları içerisindeki Rusçuk'ta doğan Rusçuklu Zarîfî, Sa'diye tarikatına intisap edip şeyhlik makamına kadar yükselmiş; 1795 yılında vefat etmiştir. Dinîtasavvufî muhtevaya sahip şiirler yazan şair, kudretin acayip sırrıdır, hikmeti bilinmez, kimi 
ekmek parçası bulamazken kimi de tatlı helva yer, diyerek yarattığı tüm varlıklara rızkı ihsan eden Hakk'in takdirine işaret eder.

'Acâ'ib sırr-1 ḳudretdir bilinmez hịikmeti anıñ

Kimi nân-pâreyi bulmaz kimi yer sükkerî ḥalvâ

Rusçuklu Zarîfî (Gönel, 2013, s. 74)

6019 beyitten oluşan hamsesi ile XVIII. yüzyıl divan edebiyatının son hamsecisi Subhizâde Feyzî ise gazelindeki bir beyitte nân-pâre ifadesini diğer şairlerimizden farklı bir şekilde buse anlaminda kullanmaktadır.

Bûs eylemem 'izârrını ben vaṣluñ isterem

Zîrâ bu nân-pâre bozar iştihâmuzı

Feyzî (İspirli, 1997, s. 698)

\section{SONUÇ}

Nân-pâre kavramı; arpalık, ikta sisteminde tahsis olunan yerler, ücret, aylık anlamlarıyla Büyük Selçuklu Devleti dönemine kadar uzanmaktadır. Osmanlı dirlik sisteminde de kullanılan kavram divan edebiyatında ise farklı anlamlarla karşımıza çıkmaktadır.

Osmanlı Devleti'nde geleneksel bir anlayışla devam ettirilen şairlerin korunması geleneği sefere çıkış, seferden dönüş, düğünler, kale fetihleri, elçi kabulleri, tayinler gibi türlü sebeplerle gerçekleştirilmiş; düzenli olarak yapılan in'âm, ihsân ve tasadduklar in'âmât defterlerinde 'îdiyye, zemistânî, bahâriyye, sâlyâne gibi ifadelerle kayıt altına alınmıştır. Nân-pâre de şairlerin bu doğrultudaki taleplerinin beyanında kullandıkları ifadelerden biridir. Farsça nân ve pâre kelimelerinin birleşmesiden meydana gelen nân-pâre ifadesi klasik Türk edebiyatında şairlerimiz tarafından gerçek, mecaz, tasavvufî ve başka anlamlarıyla ele alınmıştır. Paşa veya hâcegân meslekî durumu ne olursa olsun şairlerimiz bu kavramı şu anlamlarda kullanmışlardır:

1. Yoksulluklarının beyanında

2. Padişah, şehzade ve üst düzey memurların geçim sıkıntılarını ifade etmede, yeni mansıp talep etmede

3. Söz konusu kavram üzerinden dönemin eleştirisini yapmada

4. Tasavvufî manada rızkı ifade etmede

5. Diğer anlamlarda/bûse

Divan şairleri öncelikle gelirlerinin çok az olduğu, yetmediği noktasında bu kavramı kullanmışlardır. Kırılan, hassas bir duygu yapısına sahip şairler dünya ve hayat görüşlerinin karamsar olması sebebiyle her ne kadar yaşadıkları dünyayı geçici heves ve ızdıraplarla dolu bir yer olarak görseler, feleğin hükümlerine karşı koymanın imkânsız olduğunu söyleseler de sonuçta yaşadıkları çağın insanıdırlar. Divan şairlerine özgü bu hayata bakış anlayışı yine de onları yaşanılan hayattan kopuk, münzevî bir hayata itmemiştir.

$\mathrm{Bu}$ ifadenin XVII. yüzyıldan başlayarak ilerleyen yüzyıllarda geçim sıkıntısı/ekmek parası noktasında kullanılması toplum hayatındaki değişikliklerin özellikle de ekonominin olumsuz yönde olduğunun ipuçlarını vermektedir. Dışta sürekli savaşlar, karada ve denizde 
üst üste gelen yenilgiler, içte isyan ve türlü karışıklıklar devletin gücünün gittikçe zayıflamasına neden olmuş, otoritenin azalmasıyla birlikte her alanda huzursuzluk ve bozukluk başgöstermiştir. Divan edebiyatının siyasal ve toplumsal hayatın çalkantılarından etkilenmesi için uzunca bir süre geçmesi gerekse bile bu durum saray başta olmak üzere devlet büyüklerinin konaklarında şairlerin korunup gözetilmesini etkilemiştir. Ayrıca şairlerin farklı şiir anlayışına yönelmelerinde de toplumun bu bunalımlı hayatının etkilerini görmek mümkündür.

Divan şairlerimiz tasavvufî manada ise nân-pâre ifadesini rızık olarak mal-mülk çerçevesinde dünya ve içindekilerin geçici olduğunu, Hakk'ın her canlının rızkına kefil olduğunu bu sebeple bu gibi şeyler için uğraşının gereksiz olduğunu ifade etmede kullanmışlar, tevekkül hâlindeki kişinin rızık endişesine düşmesinin yersizliğini ifade etmişlerdir.

Maddî ihtiyaçlar, devlet işlerinde büyük memurluk/makam ve sürgündeki şairin affedilme talebi gibi sebeplerle şairlerimiz arzuhâl niteliğinde kasideler yazmışlar, şiiri, sanat göstermeyi sorunlarını aşmada veya taleplerini gerçekleştirmede en kuvvetli yol olarak görmüşlerdir. Onların bu şekilde davranmalarında geleneğin de önemli yeri olmuştur. Osmanlı'nın sanatçıyı koruma geleneğinde taraflar yani hâmî ve şairler karşılıklı kazanımlar elde etmiş, bu alışverişin gerçek kazananı ise sanat olmuştur. Şiir yüzyıllar boyunca etkisi her dönem artarak devam eden en etkili araç hâline gelmiştir.

\section{KAYNAKÇA}

Aksoyak, İ. H. ve Arslan M. (2018). Haşmet divanı. Ankara: Kültür ve Turizm Bakanlı̆̆1 Yayınları. 14 Ağustos 2020 tarihinde https://ekitap.ktb.gov.tr/Eklenti/57256,hasmetdivanipdf.pdf?0 adresinden erişildi.

Albayrak Sak, V. (2020). Mevlevi mutfak kültürünün divan şiirine yansımaları. Aş̧̧ Dede Ateşbaz-ı Veli içinde. Konya: Konya Büyükşehir Belediyesi Kültür Yayınları.

Arat, R. R. (1979). Yusuf Has Hâcib Kutadgu Bilig I. Metin. Ankara: Türk Dil Kurumu Yayınları.

Armutlu, S. (2002). Gazneliler ve Selçuklular döneminde edebî gelenek. Türkler Ansiklopedisi içinde (c. 5, ss. 872-879). Ankara: Yeni Türkiye Yayınları.

Arslan, M. (2018). Bursalı Iffet divanı. Ankara: Kültür ve Turizm Bakanlığı Yayınları 14 Ağustos 2020 tarihinde https://ekitap.ktb.gov.tr/Eklenti/59882,bursali-iffet-divanipdf.pdf?0 adresinden erişildi.

Atalar, M. (1981). Osmanlı padişahları. Ankara Üniversitesi İlahiyat Fakültesi Dergisi,24(1), 425460.

Atalay, B. (1985). Divanü Lîgat-it-Türk tercümesi I. Ankara: Türk Dil Kurumu Yayınları.

Atlansoy, K. (1998). Bursa şairleri Bursa vefeyatnamelerindeki şairlerin biyografileri. Bursa: Asa Yayınları.

Batislam, D. (2006). 16. yüzyıl divan şairi Cinânî’nin hediye konulu iki şiiri. Türklük Bilimi Araştırmaları, 20, 7-15. 
Bilkan, A. F. (1997). Nâbî divânı. İstanbul: Milli Eğitim Bakanlığı Yayınları.

Çıpan, M. (1991). Fasîh Ahmed Dede hayatı, edebî kişiliği, eserleri ve Divan'ının tenkitli metni. Yayımlanmamış doktora tezi, Selçuk Üniversitesi, Konya.

Çobanoğlu, F. (2006). Enderunlu Ferîd İbrahîm Dîvânı'nın Metni ve İncelemesi. Yayımlanmamış yüksek lisans tezi, Marmara Üniversitesi, İstanbul.

Çoruhlu, T. (2012). Tuğ. TDV İslâm Ansiklopedisi (DİA) içinde (c. 41, ss. 331). İstanbul: Diyanet Vakfı Yayınları.

Demirel, Ş. (2017). Şehrî divanı. Ankara: Kültür ve Turizm Bakanlığı Yayınları. 14 Ağustos 2020 tarihinde https://ekitap.ktb.gov.tr/Eklenti/56340,sehri-divanipdf.pdf?0 adresinden erişildi.

Devellioğlu, F. (1992). Osmanlıca-Türkçe ansiklopedik lügat. Ankara: Aydın Kitabevi.

Durmuş, T. (2009). Tutsan elini ben fakirin Osmanlı edebiyatında hamilik geleneği. İstanbul: Doğan Kitap.

Ergin, A. Ş. (1996). Yozgatlı Mehmed Said Fennî divanı. Ankara: Yozgat Belediyesi Yayınları.

Erünsal, İ. ( (1984). Türk edebiyatı tarihinin arşiv kaynakları II-Kanuni Sultan Süleyman Devrine Ait Bir İn'âmât Defteri. Osmanlı Araştırmaları, IV , 1-17.

Güler, K. ve Yaşar, K. (20079. Divan şiirinde câize (Şair, patron, hâmî ilişkisi) üzerine değerlendirmeler I. Dumlupınar Üniversitesi Sosyal Bilimler Dergisi,18, 1-35.

İnalckk, H. (2003). Şâir ve patron, patrimonyal devlet ve sanat üzerinde sosyolojik bir inceleme. Ankara: Doğu-Batı Yayınları.

İpekten, H. (1996). Divan edebiyatında edebî muhitler. Ankara: Milli Eğitim Bakanlığı Yayınları.

İpekten, H. (2019). Na’ilìi Kadìm divanı. Ankara: Kültür ve Turizm Bakanlığı Yayınları

14 Ağustos 2020 tarihinde https://ekitap.ktb.gov.tr/Eklenti/67155,naili-i-kadimdivanipdf.pdf?0 adresinden erişildi.

İsen, M. (2012). Geleneğe direnen bir şair: Nâbî. Milli Folklor, 5-8.

İspirli, S. (1997). Subhizâde Feyzî’nin hayatı, edeb̂̂ kişiliği ve hamsesi. Yayımlanmamış doktora tezi, Atatürk Üniversitesi, Erzurum.

İzbudak, V. (1991). Mesnevồ V. İstanbul: Milli Eğitim Bakanlığı Yayınları.

Kaplan, M. (2012). Hikmet şairi Yusuf Nâbî. Ankara: Şanlıurfa Valiliği İl ve Turizm Müdürlüğü Yayınları.

Karacan, T. (1981). XVIII. yüzyıl şairlerimizden Sâbit ve edisyon kritikli divan metni. Yayımlanmamış yüksek lisans tezi, Atatürk Üniversitesi, Erzurum.

Karaköse, S. (2017). Sa'id Giray divanı. Ankara: Kültür ve Turizm Bakanlığı Yayınları. 14 Ağustos 2020 tarihinde https://ekitap.ktb.gov.tr/Eklenti/55754,said-giray-divanipdf.pdf?0 adresinden erişildi. 
Kaya, B. A. (2O17). Azmizâde Hâletî dîvânı. Ankara: Kültür ve Turizm Bakanlığı Yayınları 14 Ağustos 2020 tarihinde https://ekitap.ktb.gov.tr/Eklenti/56159,azmizade-haletidivanipdf.pdf?0 adresinden erişildi.

Kutlar Oğuz, F. S. (2017). Arpaemînizâde Mustafâ Sâmî divanı. Ankara: Kültür ve Turizm $\begin{array}{lllll}\text { Bakanlığ1 } & \text { Yayınları. } & 14 & \text { Ağustos } & 2020\end{array}$ https://ekitap.ktb.gov.tr/Eklenti/56084,arpaeminizade-mustafa-sami-divanipdf.pdf?0 adresinden erişildi.

Kutlar Oğuz, F. S. (2017). Dîvân-ı İzzet ve Nigâr-nâme. Ankara: Kültür ve Turizm Bakanlı̆̆1 Yayınları. 14 Ağustos 2020 tarihinde https://ekitap.ktb.gov.tr/Eklenti/68921,divan-i-izzetve-nigar-name-pdf.pdf?0 adresinden erişildi.

Nizâmü'l-Mülk (2013). Siyasetname. (Çev.) Mehmet Taha Ayar. İstanbul: İş Bankası Yayınları.

Orkun, H. N. (1994). Eski Türk yazıtları. Ankara: Türk Dil Kurumu Yayınları.

Ögel, B. (1978). Türk Kültür Tarihine Giriş II. Ankara: Kültür Bakanlığı Yayınları.

Pakalın, M. Z. (1993). Osmanl tarih deyimleri ve terimleri sözlüğü II. İstanbul: Milli Eğitim Bakanlığı Yayınları.

Şardağ, R. (1982). Şair sultanlar. Ankara: Türkiye İş Bankası Kültür Yayınları.

Şemseddin Sami (2009). Kâmûs-i Türkî. İstanbul: İkdam matbaası (1317). İstanbul: Çağrı Yayınları.

Uzunçarşılı, İ. H. (1988). Osmanlı tarihi, IV/ I. Ankara: Türk Tarih Kurumu Yayınları.

Yenikale, A. (2017). Sünbülzâde Vehbî divanı. Ankara: Kültür ve Turizm Bakanlığı Yayınları.

Yerdelen, C. (1991). Azmîzâde Hâletî’nin rubaileri. Yayımlanmamış doktora tezi, Atatürk Üniversitesi, Erzurum. 